\title{
Use of Concrete Object Media to Improve Mathematics Learning Outcomes of Value and Equivalence of Currency Fractions
}

\section{Emila Sholikhati}

\author{
SD Margadana 8 Kota Tegal \\ emilaardisusilo@gmail.com
}

\section{Article History}

accepted 01/11/2020

approved 08/11/2020

published 15/11/2020

\begin{abstract}
This study aims to determine the increase in learning outcomes in online learning through concrete object learning media. This research is a classroom action research with the research subjects of grade II students of SD Margadana 8 Tegal City as many as 28 people. This research was conducted in 3 cycles, each cycle of 2 meetings. Each meeting consists of 4 stages, namely planning, implementing, observing and reflecting. The implementation of the research stages is slightly different from classroom learning because learning is carried out separately or students are in their respective homes. Based on the results of the research, in the first cycle, it was obtained an average of 65.36 classical student learning outcomes with $54 \%$ student completeness success, and in the second cycle it was obtained an average student learning outcomes classically 77 with completeness success increased to $79 \%$ and still being below the success indicator. In the third cycle, it was obtained the classical average of student learning outcomes 87 with the success of student completeness increased to $96 \%$ in this case it was more than the $85 \%$ achievement indicator. So from cycle I, cycle II and cycle III there is an increase in student learning outcomes. So, in this study it can be concluded that using concrete object media can improve student learning outcomes in online learning in Mathematics, the subject of value and currency denomination equivalence.
\end{abstract}

Keywords: Learning Outcomes, concrete objects, mathematics

\begin{abstract}
Abstrak
Penelitian ini bertujuan untuk mengetahui peningkatan hasil belajar dalam pembelajaran daring melalui media pembelajaran benda konkret. Penelitian ini merupakan penelitian tindakan kelas dengan subyek penelitian siswa kelas II SD Margadana 8 Kota Tegal sebanyak 28 orang. Penelitian ini dilaksanakan 3 siklus, masing-masing siklus 2 kali pertemuan. Setiap pertemuan terdiri dari 4 tahap yaitu perencanaan, pelaksanaan, observasi dan refleksi. Pelaksanaan tahap-tahap penelitian sedikit berbeda dari pembelajaran dalam kelas karena pembelajara dilakukan secara terpisah atau siswa berada dirumah masingmasing. Berdasarkan hasil penelitian, pada siklus I diperoleh rata-rata hasil belajar siswa secara klasikal 65,36 dengan keberhasilan ketuntasan siswa 54\%, dan pada siklus II diperoleh rata-rata hasil belajar siswa secara klasikal 77 dengan keberhasilan ketuntasan meningkat menjadi $79 \%$ dan masih berada dibawah indikator keberhasilan. Pada siklus III diperoleh rata-rata klasikal hasil belajar siswa 87 dengan keberhasilan ketuntasan siswa meningkat menjadi 96\% dalam hal ini sudah lebih dari indikator ketercapaian 85\%. Jadi dari siklus I, siklus II dan siklus III terjadi peningkatan hasil belajar siswa. Sehingga, dalam penelitian ini dapat disimpulkan bahwa dengan menggunakan media benda konkret dapat meningkatkan hasil belajar siswa dalam pembelajaran daring mata pelajaran Matematika materi nilai dan kesetaraan pecahan mata uang.
\end{abstract}

Kata Kunci : Hasil Belajar, benda konkret, matematika

Social, Humanities, and Education Studies (SHEs): Conference Series p-ISSN 2620-9284 e-ISSN 2620-9292 
https://jurnal.uns.ac.id/shes

\section{PENDAHULUAN}

Belajar adalah kegiatan yang berproses dan merupakan unsur yang sangat fundamental dalam penyelenggaraan setiap jenis dan jenjang pendidikan. Ini berarti bahwa berhasil atau gagalnya pencapaian tujuan pendidikan itu sangat tergantung pada proses belajar yang dialami oleh siswa

Terkait dengan upaya peningkatan kualitas belajar tersebut, salah satu yang harus dikembangkan oleh guru adalah bagaimana guru bisa menggunakan media sebagai bahan integral dalam proses pembelajaran dengan sebaik-baiknya. Dengan kata lain, seorang guru harus bisa memanfaatkan benda di sekitar sebagai media dalam kegiatan belajar mengajar meskipun program sekolah sudah terencana dengan baik.

Pada masa pandemi ini dimana pembelajaran dilaksanakan secara daring proses pembelajaran masih belum maksimal. Respon dan keaktifan siswa sangat kurang ketika mengerjakan tugas dan saat menjawab soal-soal evaluasi pada meteri nilai dan kesetaraan pecahan mata uang. Hal tersebut terjadi karena saat pembelajaran guru masih menggunakan model pembelajaran yang monoton dan cenderung membosankan. Siswa hanya diberi materi, berdiskusi dan penugasan melalui WAG dan siswa mengirimkan kembali hasil pekerjaannya yang sudah diselesaikan. Sehingga hal tersebut berpengaruh terhadap hasil belajar siswa. Berdasarkan pengamatan awal yang dilakukan di SD Margadana 8 Kota Tegal, pada siswa kelas II diperoleh nilai hasil belajar siswa pada pembelajaran Matematika materi nilai dan kesetaraan pecahan mata uang tahun pelajaran 2020/2021 masih rendah. Dari hasil pengamatan diketahui bahwa dari jumlah keseluruhan siswa kelas II sebanyak 28 siswa dengan KKM yang ditetapkan yaitu 70, hanya 5 siswa yang memperoleh nilai $\geq 70$ (18\%) dan 23 siswa memperoleh nilai $\leq 70$ (82\%). Berdasarkan permasalahan di atas, hasil pembelajaran matematika di SD Margadana 8 dikatakan kurang berhasil.

Hal ini menjadi tantangan bagi guru untuk tetap dapat menciptakan pembelajaran yang menyenangkan, menarik, aktif dan efektif yang nantinya akan berpengaruh terhadap peningkatan hasil belajar siswa.. Meskipun pembelajaran dilaksanakan jarak jauh atau daring, guru harus mampu meningkatkan motivasi siswa dalam belajar. Motivasi siswa dapat tercipta melalui penerapan media pembelajaran yang menarik. Salah satu media pembelajaran yang menarik dalam pembelajaran daring adalah dengan menggunakan media berupa benda konkret untuk meningkatkan hasil belajar siswa. Benda konkret ini berupa benda yang ada disekitar siswa dan mudah didapatkan. Hal ini sejalan dengan pendapat Oemar Hamalik tentang manfaat media benda konkret dapat memberikan pengalaman nyata yang dapat menumbuhkan kegiatan berusaha sendiri di kalangan peserta didik serta memberikan pengalaman yang tidak mudah diperoleh dengan cara lain dan membantu efisiensi dan keragaman yang lebih banyak dalam belajar

Berdasarkan uraian diatas, tujuan dilakukannya penelitian ini antara lain : untuk mengetahuai upaya peningkatan hasil belajar Matematika materi nilai dan kesetaraan pecahan mata uang dengan menggunakan media benda konkret pada siswa kelas II SD Margadana 8 Kota. 


\section{METODE PENELITIAN}

Metode penelitian yang digunakan dalam penelitian ini adalah penelitian tindakan kelas untuk meningkatkan hasil belajar siswa dalam pembelajaran daring melalui media pembelajaran benda konkret mata pelajaran Matematika materi nilai dan kesetaraan pecahan mata uang. Data yang diperoleh kemudian dianalisis menggunakan analisis diskriptif komparatif yaitu membandingkan nilai tes evaluasi setelah siklus I, siklus II dan siklus III. Data kuantitatif dalam penelitian ini adalah evaluasi hasil belajar siswa. Setelah siswa mengerjakan soal dilakukan penskoran. Penskoran ini merupakan proses pengubahan jawaban-jawaban soal tes menjadi angka-angka. Angkaangka hasil penilaian tersebut selanjutnya diubah menjadi nilai-nilai untuk mengetahui gambaran yang jelas mengenai hasil belajar siswa dalam pembelajaran Matematika

Penelitian ini dilakukan pada mata pelajaran Matematika materi nilai dan kesetaraan pecahan mata uang. Subyek penelitian adalah siswa kelas II SD Margadana 8 Kota Tegal yang melibatkan 28 siswa yang dilaksanakan pada bulan Oktober dan Nopember 2020. Instrumen pengumpulan data adalah tes evaluasi hasil belajar sedangkan teknis analisis data menggunakan teknik analisis deskriptif kualitatif dan kualitatif menggunakan kreteria pencapaian ketuntasan dengan indikator ketercapaian $80 \%$.

\section{HASIL PENELITIAN DAN PEMBAHASAN}

Dalam Penelitian Tindakan Kelas (PTK) ini menggunakan 3 siklus. Siklus aktivitas dalam PTK diawali dengan perencanaan tindakan (planning), penerapan tindakan (action), mengobservasi proses tindakan (observation), dan melakukan refleksi (reflection), dan seterusnya sampai perbaikan atau peningkatan yang diharapkan tercapai (kriteria keberhasilan).

Pada penelitian ini rencana tindakan dalam 3 siklus dengan menggunakan media pembelajaran benda konkret dan dalam satu pertemuan tersebut digunakan untuk evaluasi pembelajaran. Apabila proses pembelajaran pada siklus I belum mencapai hasil yang diharapkan maka peneliti akan melanjutkan ketahap siklus berikutnya sampai hasil yang didapatkan tercapai dengan maksimal.

Pada siklus I persentase rata-rata hasil belajar siswa dengan menggunakan media pembelajaran benda konkret sebesar 54\%. Dalam hal ini taraf keberhasilan belajar siswa termasuk dalam kategori cukup baik. Dari hasil perbaikan pembelajaran yang telah dilaksanakan pada pembelajaran siklus I diperoleh hasil analisis pengamatan tes evaluasi pelaksanaan pembelajaran pada siklus I yang telah dilakukan yang tersaji pada tabel di bawah ini :

Tabel 1. Ketuntasan Klasikal Siklus I

\begin{tabular}{c|c|c|c|}
\hline Nilai & $\begin{array}{c}\text { Banyaknya } \\
\text { Siswa }\end{array}$ & Persentase & Keterangan \\
\hline$<70$ & 13 & $46 \%$ & Tidak Tuntas \\
$\geq 70$ & 15 & $54 \%$ & Tuntas \\
\hline
\end{tabular}

Dari tabel di atas yaitu tabel ketuntasan hasil belajar siswa dapat diperjelas pada diagram di bawah ini: 


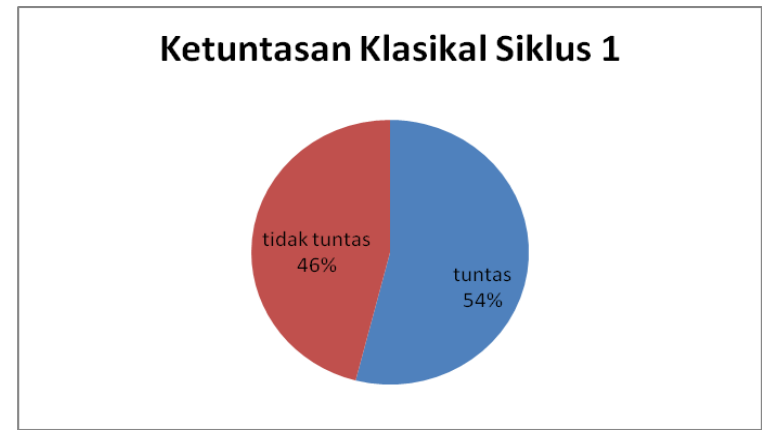

\section{Gambar 1. Diagram Ketuntasan Klasikal Siklus I}

Gambar diatas menunjukkan perbandingan persentase ketuntasan hasil belajar Matematika siklus I. Siswa yang tuntas berjumlah 15 siswa atau $54 \%$ dari jumlah keseluruhan siswa dan siswa yang tidak tuntas berjumlah 13 siswa atau $46 \%$ dari jumlah keseluruhan siswa. Secara keseluruhan ketuntasan hasil belajar Matematika pada siklus I, siswa yang mendapat nilai di atas KKM 70 masih kurang dari persentase $85 \%$ dari jumlah keseluruhan siswa.

Persentase rata-rata aktivitas belajar siswa dengan menggunakan media pembelajaran benda konkret 56\%. Dalam hal ini taraf keberhasilan belajar siswa termasuk dalam kategori cukup.

Dari hasil perbaikan pembelajaran yang telah dilaksanakan pada siklus II, diperoleh hasil nilai evaluasi belajar yang tersaji pada tabel 2 di bawah ini:

Tabel 2 Ketuntasan Klasikal Siklus II

\begin{tabular}{c|c|c|c|}
\hline Nilai & Banyaknya Siswa & Persentase & Keterangan \\
\hline$<70$ & 6 & $21 \%$ & Tidak Tuntas \\
$\geq 70$ & 22 & $79 \%$ & Tuntas \\
\hline
\end{tabular}

Dari tabel di atas yaitu tabel ketuntasan hasil belajar siswa dapat diperjelas pada diagram di bawah ini:

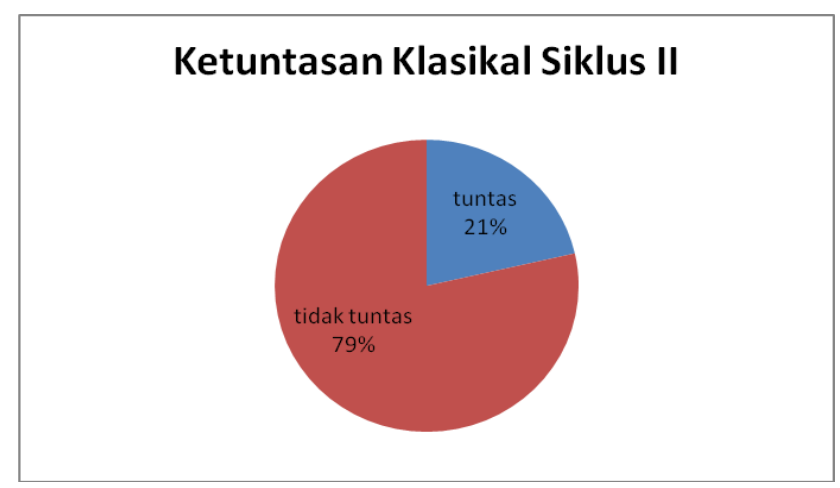

Gambar 2 Diagram Ketuntasan Klasikal Siklus II

Gambar 4.6 menunjukkan perbandingan persentase ketuntasan hasil belajar Matematika siklus II. Siswa yang tuntas berjumlah 22 siswa atau $79 \%$ 
dari jumlah keseluruhan siswa dan siswa yang tidak tuntas berjumlah 6 siswa atau $21 \%$ dari jumlah keseluruhan siswa. Dari hasil data siklus II tersebut menunjukkan peningkatan keberhasilan belajar siswa, akan tetapi jumlah prosentase ketuntasan masih berada dibawah indikator keberhasilan sebesar $80 \%$ Sehingga peneliti perlu melanjutkan tindakan penelitian ini sampai pada siklus III.

Dari hasil perbaikan pembelajaran yang telah dilaksanakan pada siklus III, diperoleh hasil nilai evaluasi belajar yang tersaji pada tabel 2 di bawahini:

Tabel 3 Ketuntasan Klasikal Siklus III

\begin{tabular}{c|c|c|c|}
\hline Nilai & Banyaknya Siswa & Persentase & Keterangan \\
\hline$<70$ & 1 & $4 \%$ & Tidak Tuntas \\
$\geq 70$ & 72 & $96 \%$ & Tuntas \\
\hline
\end{tabular}

Dari tabel di atas yaitu tabel ketuntasan hasil belajar siswa dapat diperjelas pada diagram di bawah ini:

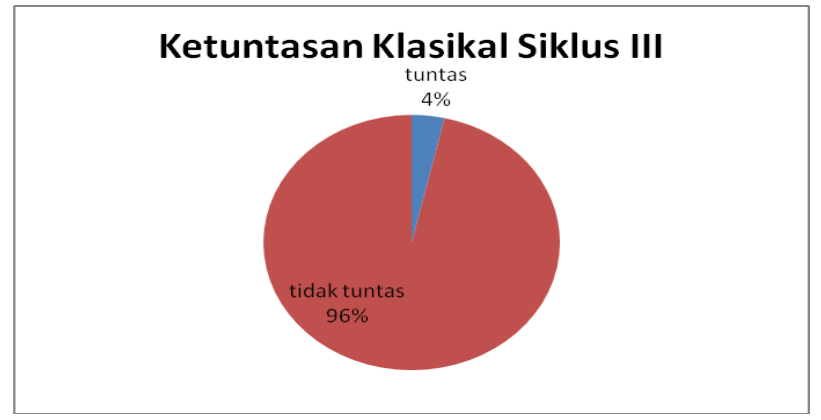

\section{Gambar 3 Diagram Ketuntasan Klasikal Siklus III}

Gambar menunjukkan perbandingan persentase ketuntasan hasil belajar Matematika siklus III. Siswa yang tuntas berjumlah 27 siswa atau 96\% dari jumlah keseluruhan siswa dan siswa yang tidak tuntas berjumlah 1 siswa atau 4\% dari jumlah keseluruhan siswa. Dari hasil data siklus III tersebut menunjukkan peningkatan keberhasilan belajar siswa, Berdasarkan nilai Kriteria Ketuntasan Minimal (KKM) mata pelajaran Matematika yaitu 70 telah tercapai pada siklus III dan telah memenuhi indikator capaian keberhasilan penelitian sebesar $80 \%$. Sehingga peneliti mengakhiri tindakan penelitian ini sampai siklus pada III.

Penggunaan media pembelajaran benda konkret dapat meningkatkan hasil belajar belajar matematika. Hasil evaluasi pembelajaran dari setiap pembelajaran yang dilakukan selalu mengalami peningkatan. Sebelum menggunakan media pembelajaran benda konkret persentase ketuntasan hanya sebesar $18 \%$. Pembelajaran siklus I dengan menggunakan media pembelajaran benda konkret keberhasilan ketuntasan mengalami peningkatan dengan menjadi 56\%. Pada pembelajaran siklus II dengan menggunakan media pembelajaran benda konkret mengalami peningkatan dengan persentase keberhasilan ketuntasan sebesar $79 \%$. Pada siklus III dengan menggunakan media pembelajaran benda konkret mprosentase ketuntasan meningkat menjadi 96\% diatas indikator keberhasilan 80 $\%$. Peningkatan nilai rata-rata siswa dari pra siklus 50,36 menjadi 65,36 pada siklus I. Pada siklus II nilai rata-rata siswa 76,79 dan meningkat menjadi 87,14 pada siklus III. 
Hasil penelitian yang telah dilakukan sebanyak 3 siklus menunjukkan bahwa media konkret mampu meningkatkan hasil belajar peserta didik. Hal ini disebabkan penggunaan media yang disesuaikan dengan materi yang diajarkan. Menurut Gagne' dan Briggs (dalam kutipan Azhar Arsyad), media meliputi alat yang secara fisik digunakan untuk menyampaikan isi materi pengajaran. Media menurut Gagne' dan Briggs ini adalah komponen sumber belajar atau wahana fisik yang mengandung materi instruksional di lingkungan siswa yang dapat merangsang siswa untuk belajar

Hasil belajar peserta didik digunakan untuk mengetahui sejauh mana pemahaman peserta didik terhadap materi pembelajaran yang dinyatakan dalam bentuk nilai. Menurut Nawawi (dalam kutipan Ahmad Susanto) menyatakan bahwa hasil belajar dapat diartikan sebagai tingkat keberhasilan siswa dalam mempelajari materi pelajaran di sekolah yang dinyatakan dalam skor yang diperoleh dari hasil tes mengenal sejumlah materi pelajaran tertentu. Adapun menurut Winkel (dalam kutipan Purwanto), hasil belajar adalah perubahan yang mengakibatkan manusia berubah dalam sikap dan tingkah lakunya. Dengan demikian peserta didik yang telah melalui evaluasi pembelajaran berarti guru berupaya memperbaiki kekurangan dari hasil yang diperoleh peserta didik.

\section{SIMPULAN}

Media pembelajaran benda konkret berupa uang asli dalam pembelajaran matematika materi nilai dan kesetaraan pecahan mata uang pada siswa kelas II SD Margadana 8 Kota Tegal penerapannya pada penelitian tindakan kelas pada saat pembelajaran siklus I, siklus II dan siklus III yaitu pada kegiatan inti. Guru memberikan contoh penggunaan media pembelajaran berupa benda konkret dan siswa dengan berkolaborasi dengan orang tua mendemonstrasikannya dirumah. Guru juga meminta siswa bekolaborasi dengan teman kelompok kecil untuk mendemonstrasikan menggunakan benda konkret berupa uang asli. Pada kegiatan penutup siswa mengirimkan video pada saat mereka berkolaborasi dengan orang tua maupun dengan temannya. Pembelajaran daring ini menggunakan bantuan WAG (whatsapp group) siswa dengan cepat mengirimkan respon mereka terhadap pembelajaran melalui voice note setelah mereka memahamai penggunaan benda konkret dalam pembelajaran. Sehingga proses pembelajaran menjadi lebih interaktif dan tidak membosankan.

Berdasarkan persentase ketuntasan hasil belajar peserta didik kelas II SDN Margadana 8 Kota Tegal setelah menggunakan media pembelajaran yaitu media konkret pada pembelajaran matematika, dapat dilihat bahwa banyaknya peserta didik yang tuntas pada siklus I sebanyak 15 peserta didik atau $54 \%$ dan banyaknya peserta didik yang tidak tuntas sebanyak 13 peserta didik atau $46 \%$. Peserta didik yang tuntas pada siklus II sebanyak 22 peserta didik atau sekitar $79 \%$ dan banyaknya peserta didik yang tidak tuntas sebanyak 6 peserta didik atau 21\%. Peserta didik yang tuntas pada siklus III sebanyak 27 peserta didik atau sekitar $96 \%$ dan banyaknya peserta didik yang tidak tuntas sebanyak 1 peserta didik atau 4\%. Aktivitas peserta didik dengan penerapan media konkret juga mengalami peningkatan dari siklus I sebesar 56\%, pada siklus II $81 \%$ dan siklus III 91\%. Aktivitas guru dari siklus I diperoleh $60 \%$, pada siklus II $72 \%$ dan siklus III $88 \%$.

Indikator keberhasilan dalam penelitian ini telah tercapai, dalam hal ini ketuntasan peserta didik secara klasikal telah mencapai $80 \%$ dengan ketuntasan $96,43 \%$ dan rata-rata hasil belajar peserta didik telah mencapai nilai $>70$ serta aktivitas peserta didik dan guru mengalami peningkatan, maka penelitian ini 
diberhentikan sampai pada siklus III. Ini berarti hasil belajar matematika pada materi nilai dan kesetaraan pecahan mata uang peserta didik kelas II SDN Margadana 8 Kota Tegal dengan menggunakan media konkret meningkat.

\section{DAFTAR PUSTAKA}

Arikunto, Suharsimi dkk., Penelitian Tindakan Kelas. Cet. XII; Jakarta: Bumi Aksara, 2014.

. Dasar-Dasar Evaluasi Pendidikan. Ed. Revisi. III; Jakarta: Bumi Aksara, 2002.

Arsyad, Azhar. Media Pembelajaran. Cet. XIX; Jakarta: RajaGrafindo Persada, 2016.

Asnawir dan Basyiruddin Usman. Media Pembelajaran. Cet. I; Jakarta: Ciputat Pers, 2002.

Djamarah, Syaiful Bahri dan Aswan Zain. Strategi Belajar Mengajar. Cet. II; Jakarta: Asdi Mahasatya, 2002.

Hamzah, Ali dan Muhlisrarini. Perencanaan dan Strategi Pembelajaran Matematika. Cet. I; Jakarta: RajaGrafindo Persada, 2014.

Ibrahim, R. dan Syaodih. Perencanaan Pengajaran. Jakarta: Rinika Cipta, 2003. Jihad, Asep dan Abdul Haris. Evaluasi Pembelajaran. Yogyakarta: Multi Pressindo, 2013.

Kementrian Agama Republik Indonesia. Al-Quran Al-Karim Samara Tajwid dan Terjemah Edisi Wanita, Surabaya: Halim, 2016.

Kunandar. Langkah Mudah Penelitian Tindakan Kelas Sebagai Pengembangan Profesi Guru. Cet. VII; Jakarta: Rajawali Pers, 2011.

Maharani, Ervina. Panduan Sukses Menulis Penelitian Tindakan Kelas Yang Simpel, Cepat, Dan Memikat. Cet. I; Yogyakarta: Parasmu, 2014.

Purwanto. Evaluasi Hasil Belajar. Yogyakarta: Pustaka Belajar, 2014.

Rusman. Model-Model Pembelajaran Mengembangkan Profesionalisme Guru. Cet. VI; Jakarta: Rajawali Pers, 2016.

S. Sadiman, Arief. Media Pendidikan Pengertian, Pengembangan, dan Pemanfaatannya. Cet. XVI; Depok: Rajawali Pers, 2012.

Sulviani, Sri. Penggunaan Media Konkret Untuk Meningkatkan Hasil Belajar Matematika Pokok Bahasan Garis Bilangan Pada Peserta Didik Kelas lii Mi Datok Sulaiman Kota Palopo, Skripsi, Program Studi Pendidikan Guru Madrasah Ibtidaiyah Fakultas IImu Tarbiyah dan Keguruan Institut Agama Islam Negeri (IAIN) Palopo, 2018.

Sudijono, Anas. Pengantar Evaluasi Pendidikan. Cet.VI; Jakarta: Raja GrafindoPersada, 2016.

Susanto, Ahmad. Teori Belajar \& Pembelajaran di Sekolah Dasar. Cet. I; Jakarta: Kencana, 2013. . Pengantar Statistik Pendidikan, Ed. Ke-I; Jakarta: Raja Grafindo Petrsada, 2009.

di Sekolah Dasar. Cet. I; Jakarta:Kencana, 2013.

Syah, Muhibin. Psikologi Pendidikan, Ed. Revisi. IX; Jakarta: RajawaliPers, 2009 